\title{
Concept based on Local Wisdom of Kaili Ethnic "Tampa Nu Bau" for Disaster Mitigation of Sea Storm
}

\author{
Muhammad Bakri ${ }^{1 *}$, Luthfiah ${ }^{1}$, and Anita Ahmad Kasim ${ }^{2}$ \\ ${ }^{1}$ Department of Architecture, Faculty of Engineering, Universitas Tadulako, Palu, Indonesia \\ ${ }^{2}$ Department of Information Technology, Faculty of Engineering, Universitas Tadulako, Palu, \\ Indonesia
}

\begin{abstract}
Sea Storm or tidal waves are one of the natural disasters that impose risks to human life. One of those potentially threatened by sea storms is fishermen who are fishing. Mitigation of sea storms is not only carried out on land but also at sea. Local wisdom has been used as an effort to mitigate disaster. This study aims to find the concept of space-based on a community's local wisdom in disaster mitigation. Kaili tribe is one of the ethnic groups living in Sulawesi, especially in Central Sulawesi province. The proposed concept of space is "Tampa Nu Bau" concept, which in the Kaili language means a space located at sea and serves as a transit space for fishermen when fishing. The method used in this research is phenomenology. This method is done by observing the behavior of fishermen, behavior mapping, ethnic wisdom behavior and superimposition which are often shown by fishermen when using the "Tampa Nu Bau" room. The results obtained in this study are the concept of space-based on local wisdom that can reduce the risk of storm disasters in the Sea
\end{abstract}

\section{Introduction}

Tidal waves or sea storms are water rise up and lower down movements of the sea to form valleys and hills following the wave motion. There are two types of sea waves. First are short period sea waves that are usually generated by the wind blowing on the sea surface. Second are long-period sea waves. This wave has a longer duration. This is caused by strong winds, solar gravity and the distance of the moon to the earth, or earthquakes. Several natural processes occur at the same time to influence the long period of sea-level variation.

Tidal wave magnitude and time of occurrence are easily predicted and measured, while the occurrence of tsunami waves and storm waves are rather difficult to predict. Storm waves are huge, high, and strong waves that arise due to the effects of tropical cyclones around the Indonesian territory. These waves have a strong potential to cause natural disasters. Indonesia is not located within a tropical cyclone trajectory, but the existence of tropical cyclones will have strong impacts on the occurrence of strong winds and high waves accompanied by heavy rain.

\footnotetext{
* Corresponding author: embakri@gmail.com
} 
Physically, tropical cyclones are low-pressure air systems that have rotating winds (cyclonic) originating from tropical areas with an average speed of 34-64 knots around the centre of the storm. High-speed winds occurring above the sea surface can generate a large fluctuation of the sea level along the coast, particularly if the storm is quite strong and the coastal area is shallow and wide. The occurrence of tropical cyclones, full moon tides, and earthquakes followed by tsunamis are the cause of sea storms. Those at risk of sea storm threats are fishermen who are fishing.

Indonesia has a cultural diversity that spreads from Sabang to Merauke. The culturally diverse knowledge combined with mastery of technology makes culture an important element in solving problems in the lives of Indonesian people. Local wisdom has been used as a tool to solve various problems in the urban community. Local wisdom is owned by all tribes in Indonesia, one of which is the Kaili tribe. Kaili is one of the ethnic groups residing in Sulawesi, precisely in the Central Sulawesi province. Kaili tribe people in Palu City live in the coastal area of Talise. The livelihood of the Kaili tribe is fishing. This study aims to find the concept of space based on the local wisdom of the Kaili people regarding disaster mitigation. One local wisdom in the Kaili community is "Татра пи Ваи" in the sea. This paper consists of five parts i.e., introduction, literature review, method of study, results, and discussion, and conclusions.

\section{Literature Review}

Local wisdom values are taught by Indonesia's ancestors due to their awareness of human dependence on nature and its surrounding environment. Local ethnic wisdom plays an important role in the management of natural resources and the environment. The prospect of applying local wisdom in the future depends largely on community knowledge, technological innovation, market demand, the use and conservation of biodiversity in the environment. Besides, local wisdom also depends on government policies that are directly related to the management of natural resources and the environment. Krueng Sabee is one area that is often hit by natural disasters in Aceh Jaya Regency, Aceh Province. This area adopted local wisdom values for mitigating natural disasters such as floods, earthquakes, tsunamis, and almost extinguished forest conservation[1]

Research on the utilization of local wisdom in disaster mitigation has been conducted at almost all of the islands in Indonesia. Local wisdom can take form in life philosophy, attitudes, and behavioral guidelines. This will help the community to stand against various threats that disrupt their existence, from natural disasters and the dynamics of life. Sundanese, especially in Kampung Naga Tasikmalaya, have their own local wisdom to protect the surrounding environment. Environmental protection is very important to minimize disasters, such as landslides, droughts, and pollution. Communities realize that natural disasters will occur from environmental damage [2]

Local wisdom in disaster mitigation can be seen in architecture, land-use zoning, and land management for a sustainable environment. The prevalent lore is to bring society closer to the true core of life. The myth that exists in society makes people able to find their relationship with the universe and the Creator. Myth teachings inspire people to be nurturing and develop a harmony of living together in the social order between macro-cosmos, microcosmos, and the Invisible. The Rote Ndao people have been able to deal with earthquake disasters by practicing local wisdom that has been trusted for generations [3]

The people of Central Sulawesi in general and especially the people of Kaili tribe have various forms of local wisdom, for example, in expressions, taboos, and traditional ceremonies. Some of its adherents are still found in every traditional community group. Expressions have their roots in language that contain interpretative meaning and symbolism. 
This allows people to interact with each other based on interpretations of these expressions. Kaili is the largest ethnic population compared to other tribes that are spread across several regencies in Central Sulawesi. This tribe knows more than twenty languages that are still used in everyday conversation.

However, the Kaili tribe has "lingua pranca" known as the "Ledo" language. The word Ledo means "no". The Ledo language is used to communicate with other Kaili languages, and there are native languages still found that have not been made impure by immigrant language use around Raranggonau and Tompu. The Ledo language used by Kaili people in Palu, and Biromaru (Kaili Ado, Kaili Tara, Kaili Ija, Kaili Edo), Donggala (Unde and Doi), and Parigi and its surroundings (Kaili Tara and Rai) languages have all been assimilated and contaminated with several immigrant languages, especially Bugis and Malays. All the basic words of the languages mentioned mean "no" [4]

In Ambon, local knowledge about natural disasters was obtained through years of experience. Knowledge and experience are transmitted from generation to generation through song or art. Various songs and art in Ambon can be interpreted as an attempt to warn future generations about the history of disasters that have occurred in the region. Songs entitled Tulehu and Banjala Galala in Ambon are examples of local wisdom that can function as disaster mitigation [5]

Local wisdom about disaster mitigation in traditional buildings is carried out by the Baduy tribe. The technology owned by the Baduy people in building construction is still relatively simple but contains their environmental wisdom. The construction of a Baduy house generally takes the form of a simple stage house made of wood, bamboo, palm fiber, and thatch. These stage houses are almost all the same size. According to Balimbing villagers (Baduy Panamping) about the same and simple houses, “...kudu sarua ulah aya anu luhur handapan hirup sadarahana..." (which means, all must be the same, there should be no high or low, and, live in simplicity). This statement also means the equality of every Baduy people in his life in the world. According to their belief, they will be different if they are already in the hereafter [6]

Local wisdom is indigenous knowledge derived from the accumulation of generations of people living in certain environments. This knowledge is maintained and belongs to the community in that environment. Local wisdom is basic information for the community. It can facilitate communication and decision making it is dynamic, and it is consistently influenced by internal creativity and experimentation and contact with external systems. Local wisdom also includes the community's skills, experiences, and insights applied to maintain or improve livelihoods. Indigenous knowledge is developed and continuously adapted for environments, changed gradually and passed down from generation to generation, and closely intertwined with cultural values of the society [7]

\section{Method of Study}

The method used in this study is phenomenology by observing fishermen's behavior, behavior mapping, and superimposing the cognitive behavior that is often showed by fishermen in utilizing the "Tampa Nu Bau" space. Etymologically, the term phenomenology is derived from the word's phenomenon and logos. The phenomenon comes from the Greek verb "phainesthai" which means to appear and is formed from the root words of fantasy, phantom, and phosphorus which means light. From that word, a verb 'appear' is created and is visible because it glows. In Indonesian, it means light. The phenomenon is interpreted as a symptom or something that appears.

The Phenomenon can be viewed from two perspectives. First, phenomena always "point out" or relates to reality out of mind. Second, phenomena are from the perspective of one's consciousness because phenomenology is always within human consciousness. Therefore, in 
looking at phenomena, we must first identify a filtering/ratio, to represent pure awareness. Phenomenology is a science of the essence of the ideal consciousness and the essence of objects as a correlation with consciousness.

Phenomenology is also a philosophical approach to investigate human experience. Phenomenology means a way of thinking to acquire new knowledge or to develop the existing knowledge with logical, systematically critical steps, without a priori / prejudice, and without dogma. Phenomenology as a method is not only used in philosophy but also in the social sciences and education. Phenomenological research involves careful and detailed testing of an awareness of human experience. The main concept in phenomenology is meaning. Meaning is an important essence that arises from the experience of human consciousness. A meticulous analysis is carried out to identify the essential qualities of awareness experiences [8].

\section{Results and Discussion}

The spatial process of fishermen in Palu bay starts from the original occupancy until it reaches the fishing point location. The spatial structure was formed on beliefs that were handed down through generations until today. This spatial concept forms a pattern of relatedness between spatial elements in order to support fishermen's privatization when conducting activities. The concept of Nakappali Spatial Pattern among fishermen's community of Palu Bay can be seen in Figure 1.
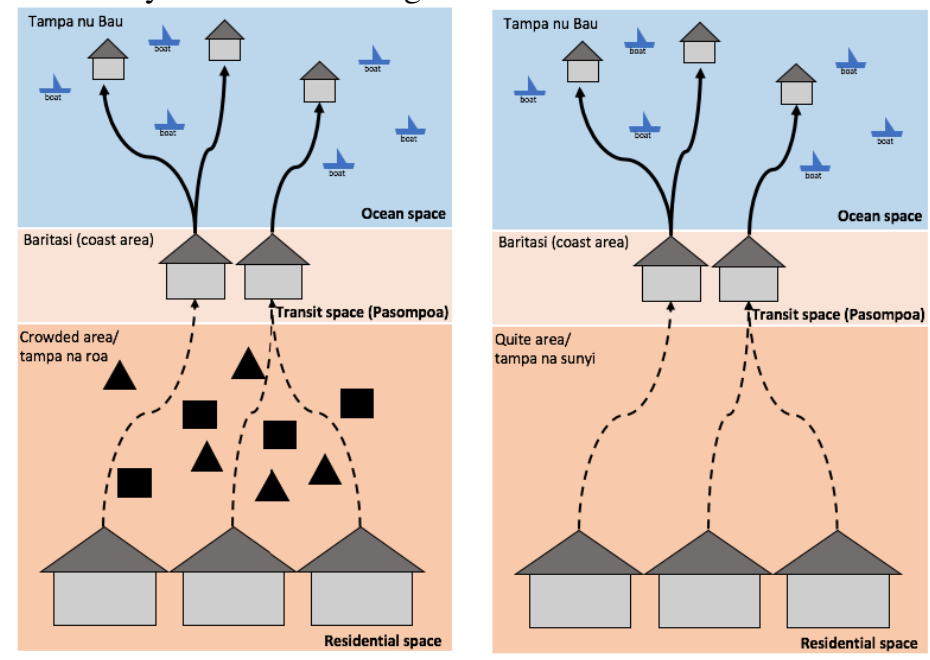

Fig. 1. The concept of Nakappali Spatial Pattern among fishermen's community of Palu Bay

Tampa пи bau is a place where livelihoods are carried out related to fulfilling the daily needs of the local community. Fishermen movements from a transit area usually go directly to the activity area, which has been previously marked both by intuition and by installing a float made of bamboo or floating materials. The Tampa nu Bau area is a gathering place for fishermen in the sea and when there is a big wave that will endanger the fishermen at sea, a temporary refuge place is needed while waiting for the storm to subside. Installation of buoys from bamboo or floating materials is one mitigation effort of the Kaili community for the approaching big waves of the sea. The installation of buoys from bamboo or floating materials is re-modeled so that they are not only limited to buoys of bamboo or floating materials but also can be a refuge for fishermen when big waves occur at sea. 
The sea space on the Tampa Nu Bau area was designed. The temporary shelters are built using materials that can float like bamboo. The shelter place in the Tampa nu Bau area was used as a resting area and the gathering area of fishermen in the sea. This temporary shelter also serves as a sanctuary when there is a storm in the sea. The material structure used allows the temporary shelters in taтра пи ваи area to minimize the human risk of natural disasters occurring at the sea.

\section{Conclusion}

The results obtained in this study inform that the concept of space-based on local wisdom can reduce the human risk of storm disasters in the Sea. The "Tampa nu Bau" area shelter arrangement concept can be used as a conventional space or as a mitigating temporary shelter for fishermen during a storm in the sea.

\section{References}

1. D. Hermon and R. Wilis, "The Formulation of Natural Disaster-Based Local Wisdom Values After Tsunami Disaster in Aceh Jaya District, Aceh Province, Indonesia," Res. Humanit. Soc. Sci., vol. 6, no. 16, pp. 120-124, 2016.

2. E. Maryani, A. Yani, and K. Naga, "Local Wisdom Of Kampung Naga In Mitigating Disaster And Its Potencies For Education,” vol. 14, pp. 72-85, 2014.

3. J. Thene, "Mitigasi Bencana Gempa Bumi Berbasis Kearifan Lokal Masyarakat Rote Kabupaten Rote Ndao Provinsi Nusa Tenggara Timur," J. Teor. dan Praksis Pembelajaran IPS, vol. 1, 2016.

4. S. Saleh, "Kearifan lokal masyarakat kaili di sulawesi tengah," J. Acad., vol. 05, no. 02, pp. 1126-1134, 2013.

5. I. Alwi, R. Mustansyir, and P. H. Hadi, "Natural Disaster Managements In Indonesia : Perspective of Local Wisdom and Heidegger Hermeneutics," Al Albab, vol. 6, no. 1, pp. 79-96, 2017.

6. R. Cecep, E. Permana, I. P. Nasution, and J. Gunawijaya, "Kearifan Lokal Tentang Mitigasi Bencana Pada Masyarakat Baduy,” MAKARA, vol. 15, no. 1, pp. 67-76, 2011.

7. M. Cadrin, D. M. S. Rana, and K. H. Sarker, Local Wisdom : Indigenous Practices for Mitigating Disaster Loss. 2012.

8. M. Bakri, “'Conformism' Space of Local Community Against Tourism Community's space in Tourism area of Teluk Palu," in Proceding Journal of Indigenous communities and "the projects of modernity" international seminar, 2012, pp. 1-11. 